\title{
Implementasi Aplikasi Speech to Text untuk Memudahkan Wartawan Mencatat Wawancara dengan Python
}

\author{
I Komang Setia Buana \\ Politeknik Siber Dan Sandi Negara \\ e-mail: komang.setia@stsn-nci.ac.id \\ Diajukan: 8 April 2020; Direvisi: 19 Juni 2020; Diterima: 1 Juli 2020
}

\begin{abstract}
Abstrak
Wawancara merupakan kegiatan komunikasi melalui proses pertukaran informasi antara reporter dan sumber berita. Banyak wartawan lebih sibuk mencatat pada saat wawancara sehingga hasil wawancara tidak efektif. Oleh karena itu dibutuhkan alat perekam untuk merekam jawaban dari narasumber. Akan tetapi alat perekam dibutuhkan waktu untuk mendengarkan hasil rekaman, kemudian mencatatnya. Padahal dituntut untuk mengumpulkan 3 sampai 4 berita dalam sehari. Dalam ilmu komputer terdapat bidang ilmu yaitu Speech to Text, teori ini akan bermanfaat untuk kondisi tersebut. Speech to text merupakan fitur untuk mengubah suara menjadi teks. Keunggulannya adalah layanan pengenalan suara. Speech to Text berfungsi untuk memanajemen waktu agar lebih efektif. Umumnya kecepatan berbicara dengan kecepatan mencatat berbeda. Sehingga hal tersebut menyulitkan wartawan yang bertugas. Disisi lain, teori ini akan sangat berguna bagi kaum disabilitas. Karena user atau pengguna hanya perlu menggunakan suara untuk melakukan aktivitas mengetik selayaknya orang normal pada umumnya. Dari permasalahan tersebut, dibuatkan aplikasi yang bisa mengubah suara ke dalam suatu teks/tulisan dengan menggunakan bahasa pemrograman Python. Untuk melakukan proses mengubah suara menjadi teks menggunakan modul speech recognition. Uji coba menggunakan 6 sample audio hasil rekaman, didapat bahwa dengan menggunakan bahasa pemrograman Python, mampu mengonversi suara ke tulisan dengan tingkat keberhasilan mencapai 94,75\%.
\end{abstract}

Kata kunci: Wartawan, Wawancara, Python, Speech to text.

\begin{abstract}
Interviews are communications through the process of exchanging information between reporters and news sources. The journalist is required to write notes and take down crucial points in a short period of time, making the results of the interview otherwise ineffective. To combat these problems a recording device can be ideal in situations like these. Even though listening to a playback of the recording may take more time for a journalist to produce a finished and edited version of their interview. With journalists having to write 3 to 4 articles per day and having to conduct many interviews, you can see how this can become a difficult feat. This is where speech to text comes into play. Speech to text is a new and effective strategy that journalists use to help them convert the recording of an interview into proper text. Imagine how much more effective, in a shorter period of time, you can be if this software was used in the field. Another advantage of speech to text is its effectiveness in helping people who might lack proper writing skills but are proficient in speech. A useful application in converting speech into text is "Python". Python is one of the main applications that are responsible for converting speech into text by using a speech recognition module. To prove its effectiveness, Python conducted a trial using 6 recorded audio samples. The trial concluded that while using Python, they were able to convert speech into writing with a 94,75\% success rate.
\end{abstract}

Keywords: Reporters, Interviews, Python, Speech to text.

\section{Pendahuluan}

Wawancara atau interview merupakan kemampuan dasar jurnalistik yang sangat penting. Wawancara merupakan kegiatan komunikasi melalui proses pertukaran informasi antara reporter dan narasumber. Berita yang baik adalah berita yang dihasilkan dari sebuah penggalian informasi yang terampil. Oleh karena itu dibutuhkan jurnalis yang harus benar-benar fokus dan memperhatikan jawaban narasumbernya. Banyak wartawan yang pada saat melakukan wawancara tidak mampu fokus dengan 
pernyataan yang dikemukakan oleh narasumber yang disebabkan karena fokus mencatat [1]. Oleh karena permasalahan tersebut, dibutuhkan alat perekam untuk merekam jawaban dari narasumber. Akan tetapi menggunakan alat perekam membutuhkan waktu lagi untuk mendengarkan hasil rekaman kemudian mencatatnya, padahal wartawan dituntut untuk mengumpulkan berita sebanyak 3 sampai 4 dalam sehari.

Di dalam ilmu komputer terdapat bidang ilmu yang disebut dengan Speech to Text. Speect to Text mengonversi teknis ke teks yang mengambil input dari microphone dalam bentuk suara kemudian dikonversi ke tulisan yang ditampilkan di desktop [2][3]. Pengenalan suara merupakan istilah ilmu komputer dan juga dikenal sebagai pengenalan suara otomatis. Ini adalah fitur untuk mengubah suara menjadi teks. Salah satu keunggulan utama untuk layanan pengenalan suara adalah pengurangan kesalahan ejaan kata-kata yang mungkin terjadi oleh seseorang saat mengetik. Disisi lain, penerapan Speect to Text akan sangat berguna bagi kaum disabilitas. Karena user atau pengguna hanya perlu menggunakan suara untuk melakukan aktivitas mengetik selayaknya orang normal pada umumnya. Keuntungan keseluruhan adalah manajemen waktu. Kebanyakan orang dapat berbicara lebih cepat daripada mereka melakukan pengetikan [4].

Dari permasalahan yang dialami oleh wartawan pada saat mengolah hasil rekaman yang dituangkan dalam bentuk tulisan, maka dibuatkan aplikasi yang bisa mengubah suara yang berasal dari narasumber ke dalam suatu teks/tulisan. Dalam pembuatan aplikasi penulis menggunakan bahasa pemrograman Python 3.8.1.

\section{Metode Penelitian}

Perancangan sistem dalam penelitian ini dibagi menjadi dua kegiatan yaitu pengambilan data dan pengolahan data. Pengambilan data adalah hal yang dilakukan pertama kali, setelah itu data yang sudah diambil diolah menggunakan aplikasi.

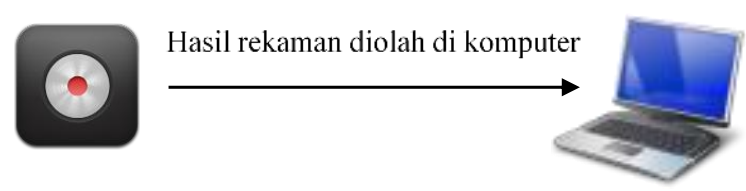

Gambar 1. Arsitektur Sistem

Gambar 1 memperlihatkan arsitektur sistem, di mana hasil rekaman yang sudah didapat diproses oleh aplikasi Python. Format file rekaman harus .wav karena aplikasi hanya bisa mendeteksi file format .wav saja. Alur kerja sistem dijelaskan seperti Gambar 2 berikut.

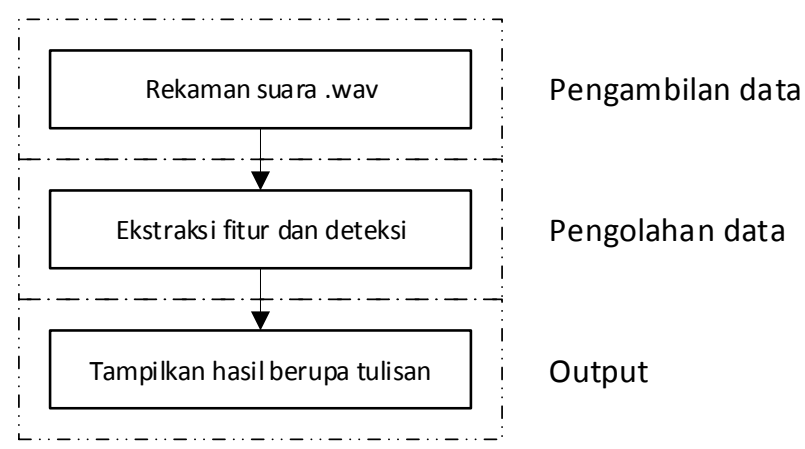

Gambar 2. Alur kerja sistem.

\subsection{Pengambilan Data}

Data didapat dari hasil rekaman suara orang atau merekam suara berita dari Youtube dengan menggunakan aplikasi handphone.

\subsection{Pengolahan Data}

Dalam melakukan pengolahan data, rekaman suara harus sudah disiapkan terlebih dahulu. Sebenarnya aplikasi yang dibuat bisa secara realtime mengubah suara ke teks dengan menyiapkan microphone. Akan tetapi karena aplikasi berupa desktop sehingga sangat menyusahkan kalau membawa komputer atau laptop ke mana-mana, sehingga lebih efisien hasil rekaman diolah langsung ke laptop. 
Tahap pengolahan data untuk bisa mendeteksi suara dan menampilkan tulisan:

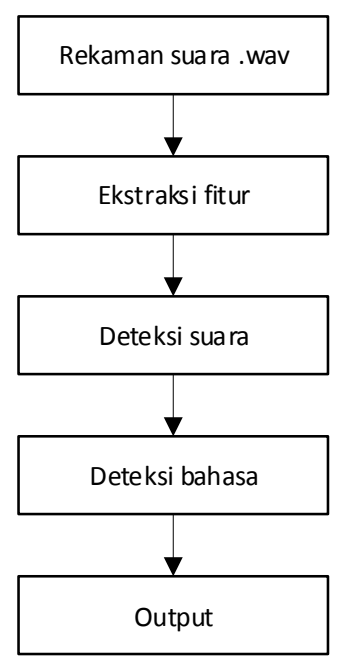

Gambar 3. Pengolahan data output tulisan.

Tahap pengolahan merupakan tahap inti dari sistem yang akan dirancang. Tahap pengolahan dibagi menjadi beberapa proses:

1. Tahap Ekstraksi Fitur

Ekstraksi Fitur adalah bagian terpenting dari pengenalan suara karena ia memainkan peran penting untuk memisahkan satu ucapan dari yang lain. Karena setiap suara memiliki karakteristik yang berbeda yang tertanam dalam signal suara [5]. Untuk ekstraksi fitur dilakukan perbaikan noise dengan menggunakan algoritma FastICA. FastICA merupakan suatu algoritma yang ditujukan untuk melakukan proses ekstraksi berdasarkan algoritma ICA. Metode ICA akan diterapkan untuk memisahkan antara suara asli atau suara baik dengan suara gangguan (noise), sehingga dapat diperoleh suara yang mempunyai kualitas yang lebih bagus. File yang akan diperbaiki sudah tercampur dengan noise, maka diasumsikan proses pencampuran file dengan noise adalah untuk membuat sebuah variabel yang mempunyai nilai BA (dominan noise). Prinsip ICA untuk memisahkan dua sumber bunyi adalah dengan diketahui kedua variabel sumber tercampur $\mathrm{AB}$ dan sumber tercampur BA. Dengan pencampuran dua sumber itu maka variabel yang dibutuhkan sudah terpenuhi, sehingga persamaan FastICA dapat dilakukan untuk mendapatkan nilai A dengan B. File yang rusak pada mulanya mempunyai nilai $\mathrm{AB}$ dengan persamaan ICA nilai B pada AB semakin direduksi sehingga didapatkan nilai A yang hampir independent [6][7].

2. Tahap Deteksi Suara

Tahap deteksi suara menggunakan bahasa pemrograman Python dengan menggunakan modul speech recognition. Untuk menggunakan modul speech recognition, di dalam source code import modul tersebut. Perintah awal yang diperlukan dalam speech recognition adalah Recognizer(). Karena akan menggunakan suara rekaman sehingga menggunakan method record() yang berada di Recognizer(). Try \& Except digunakan untuk deteksi error yang terjadi pada saat proses deteksi suara.

\section{Tahap Deteksi Bahasa}

Pada tahap ini suara yang berasal dari narasumber dideteksi dan hanya menggunakan bahasa Indonesia. Ketika menggunakan bahasa Inggris atau bahasa lain, hasil tulisan yang didapat kurang sempurna karena di dalam coding speech recognition sudah diset ke bahasa Indonesia. Untuk melakukan deteksi bahasa harus terkoneksi internet karena modul speech recognition terhubung dengan Google Speech Recognition dengan sintak recognize_Google (audio, language = 'in').

4. Output

Output yang dihasilkan berupa tulisan yang akan digunakan oleh wartawan untuk membuat berita.

Implementasi Aplikasi Speech to Text untuk Memudahkan Wartawan Mencatat Wawancara dengan Python (I Komang Setia Buana) 


\subsection{Instrumen Penelitian}

Adapun instrumen penelitian yang digunakan pada penelitian ini adalah:

1. Laptop Lenovo Y50 Intel Core i7

2. Software Python 3.8.1

3. Smartphone Android, OPPO A5

4. Windows 10 Enterprise

\section{Hasil dan Pembahasan}

Hasil dari aplikasi ini adalah untuk mendeteksi suara yang didapat dari rekaman suara orang atau rekaman dari Youtube. Penulis menggunakan suara Youtube karena di Youtube tersebut selain ada suara orang juga ada backsound musik yang menutupi suara orang tersebut. Sehingga suara musik tersebut bisa dijadikan sample noise. Penulis menggunakan suara orang langsung untuk menguji coba menggunakan suara langsung. Pada saat perekaman suara langsung penulis menghidupkan musik dan membuat suara gaduh dengan memukul-mukul meja untuk mendapatkan noise dari rekaman tersebut. Sample data yang digunakan ada 6 sample dengan tingkat noise sesuai yang dibuat oleh penulis yaitu:

a. Noise sedikit jika suara orang lebih dominan dari suara noise.

b. Noise banyak jika suara orang sama atau lebih kecil dari suara noise.

Tabel 1. Sample audio.

\begin{tabular}{|c|c|c|c|}
\hline No & Nama file & Durasi & Noise \\
\hline 1 & Sample1.wav & 17 detik & sedikit \\
\hline 2 & Sample2.wav & 20 detik & banyak \\
\hline 3 & Sample3.wav & 33 detik & sedikit \\
\hline 4 & Sample4.wav & 1 menit & banyak \\
\hline 5 & Sample5.wav & 1 menit 32 detik & banyak \\
\hline 6 & Sample6.wav & 2 menit & sedikit \\
\hline
\end{tabular}

Dari sample audio yang digunakan menggunakan 6 sample dengan durasi yang berbeda-beda. Didapat hasil sebagai berikut:

Tabel 2. Hasil pengujian aplikasi.

\begin{tabular}{clccc}
\hline No & Nama File & Jumlah Kata & Kata yang Terdeteksi & Persentase \\
\hline 1 & Sample1.wav & 10 & 10 & $100 \%$ \\
\hline 2 & Sample2.wav & 32 & 28 & $87,5 \%$ \\
\hline 3 & Sample3.wav & 52 & 50 & $96,2 \%$ \\
\hline 4 & Sample4.wav & 78 & 70 & $89,7 \%$ \\
\hline 5 & Sample5.wav & 156 & 149 & $95,6 \%$ \\
\hline 6 & Sample6.wav & 186 & 185 & $99,5 \%$ \\
\hline & & Total persentase keberhasilan & $94,75 \%$ \\
\hline
\end{tabular}

Penjelasan dari Tabel 2 seperti berikut :

1. Menggunakan file sample1.wav dengan durasi 17 detik.

Sample audio yang digunakan dengan merekam suara sendiri.

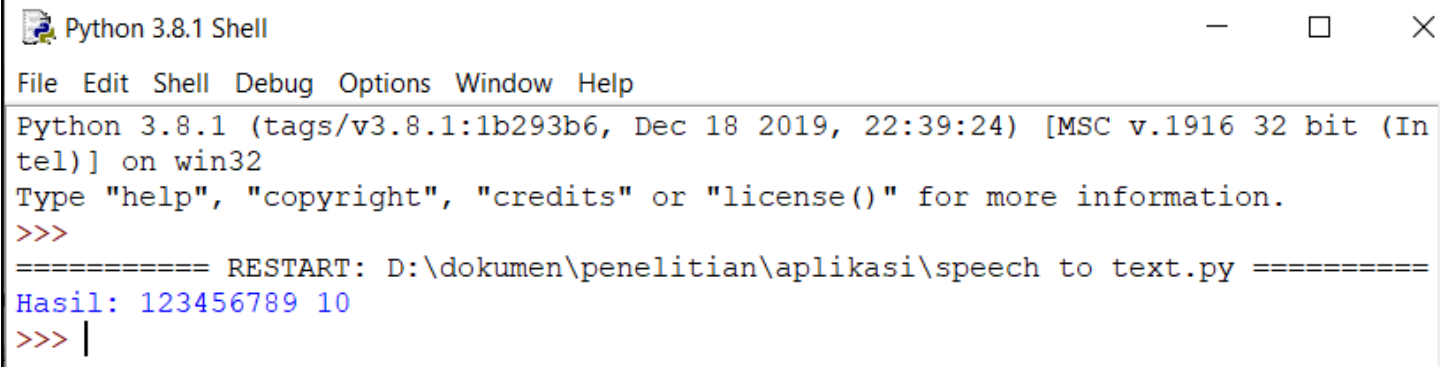

Gambar 4. File audio durasi 17 detik. 
Dari hasil yang terlihat pada Gambar 4, hasilnya berupa angka, di mana suara yang direkam berupa kalimat. Hasil dari aplikasi $100 \%$ berhasil diterjemahkan ke teks dengan durasi 17 detik, sesuai dengan Gambar 4.

2. Menggunakan file sample2.wav dengan durasi 20 detik.

Sample audio yang digunakan dengan merekam suara di Youtube.

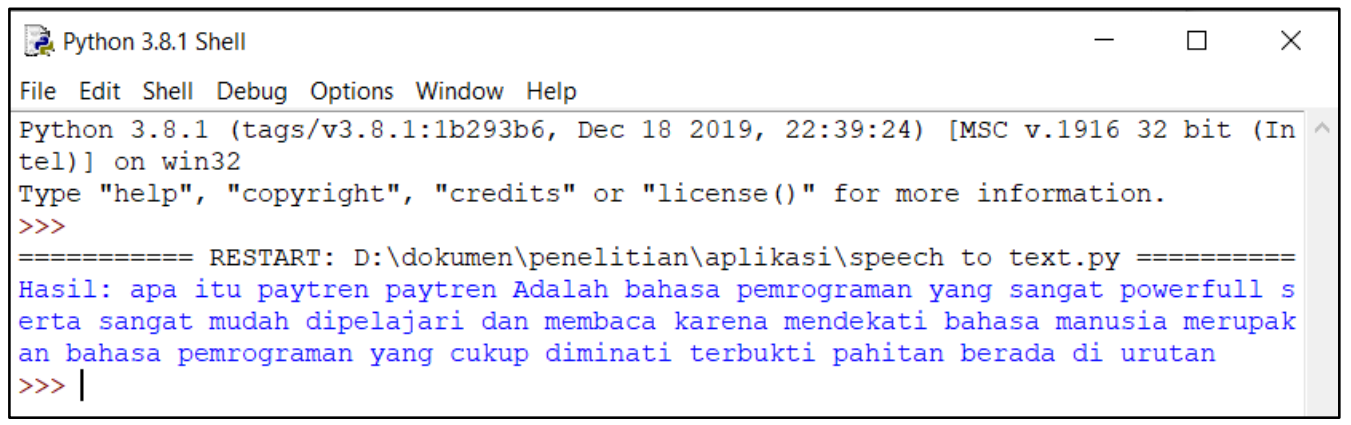

Gambar 5. File audio durasi 20 detik.

Gambar 5 merupakan hasil yang didapat dengan durasi 20 detik. Isi berita dari audio sample2.wav yaitu "Apa itu Python? Python adalah bahasa pemrograman yang sangat powerfull, serta sangat mudah dipelajari dan dibaca, karena mendekati bahasa manusia. Python merupakan bahasa pemrograman yang cukup diminati, terbukti Python berada di urutan...”. Dari hasil pada Gambar 5, terlihat bahwa dari 32 kata dengan durasi 20 detik, dapat menerjemah secara benar sebanyak 28 kata. Dari data tersebut, hasil dari aplikasi 87,5\% berhasil diterjemahkan ke teks.

3. Menggunakan file sample3.wav dengan durasi 33 detik.

Sample audio yang digunakan dengan merekam suara sendiri.

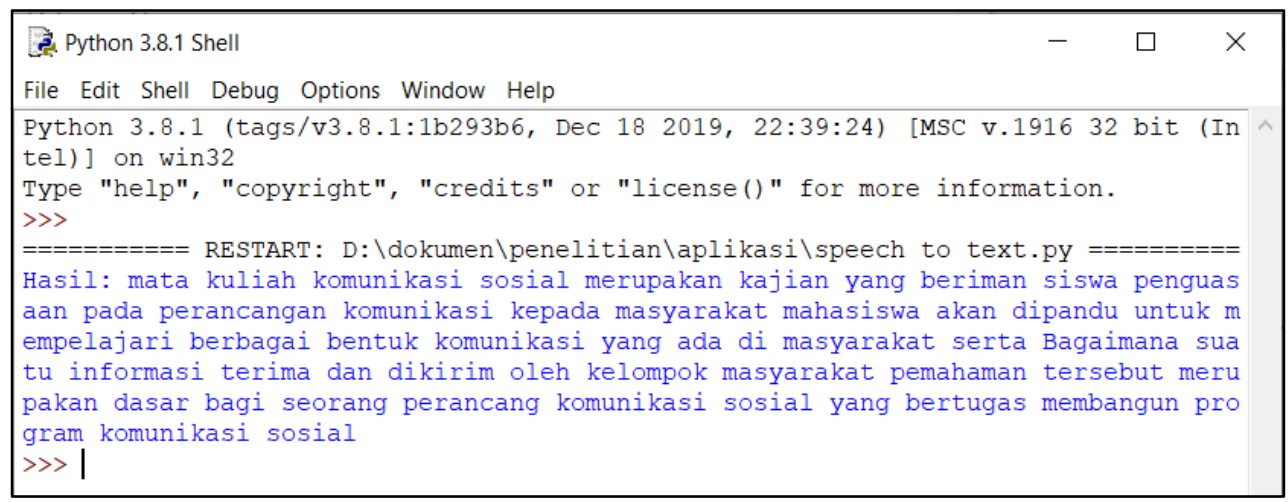

Gambar 6. File audio durasi 33 detik.

Gambar 6 merupakan hasil yang didapat dengan durasi 33 detik. Isi berita dari audio sample3.wav yaitu "Mata kuliah komunikasi sosial merupakan kajian yang memberi mahasiswa penguasaan pada perancangan komunikasi kepada masyarakat. Mahasiswa akan dipandu untuk mempelajari berbagai bentuk komunikasi yang ada di masyarakat, serta bagaimana suatu informasi terima dan dikirim oleh kelompok masyarakat. Pemahaman tersebut merupakan dasar bagi seorang perancang komunikasi sosial yang bertugas membangun program komunikasi sosial." Dari hasil pada Gambar 6, terlihat bahwa dari 52 kata dengan durasi 33 detik, dapat menerjemah secara benar sebanyak 50 kata. Dari data tersebut, hasil dari aplikasi $96,2 \%$ berhasil diterjemahkan ke teks.

4. Menggunakan file sample4.wav dengan durasi 1 menit.

Sample audio yang digunakan dengan merekam suara di Youtube. 


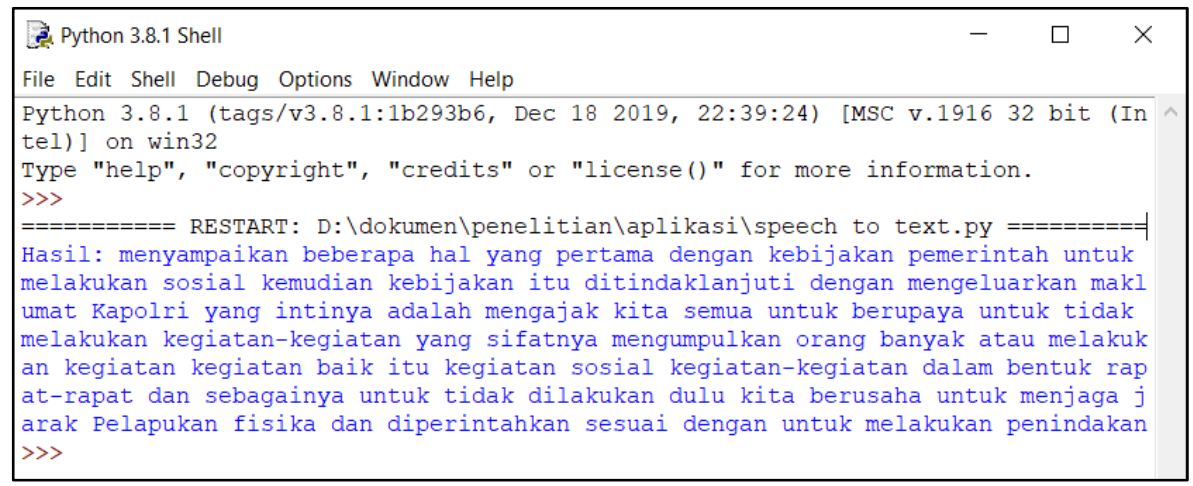

Gambar 7. file audio durasi 1 menit

Gambar 7 merupakan hasil yang didapat dengan durasi 1 menit. Isi berita dari audio sample4.wav yaitu "Menyampaikan beberapa hal yang pertama seiring dengan kebijakan pemerintah untuk melakukan sosial distancing, fisikal distancing kemudian kebijakan itu ditindaklanjuti oleh Bapak Kapolri dengan mengeluarkan maklumat Kapolri yang intinya adalah mengajak kita semua untuk berupaya untuk tidak melakukan kegiatan-kegiatan yang sifatnya mengumpulkan orang banyak atau melakukan kegiatan, baik itu kegiatan sosial, kegiatan-kegiatan dalam bentuk rapat-rapat, dan sebagainya, untuk tidak dilakukan dulu, kita berusaha untuk menjaga jarak, melakukan fisikal distancing secara disiplin dan diperintahkan sesuai dengan maklumat untuk melakukan penindakan”. Dari hasil pada Gambar 7, terlihat bahwa dari 78 kata dengan durasi 1 menit, dapat menerjemah secara benar sebanyak 70 kata. Dari data tersebut, hasil dari aplikasi $89,7 \%$ berhasil diterjemahkan ke teks.

5. Menggunakan file sample5.wav dengan durasi 1 menit 32 detik.

Sample audio yang digunakan dengan merekam suara di Youtube.

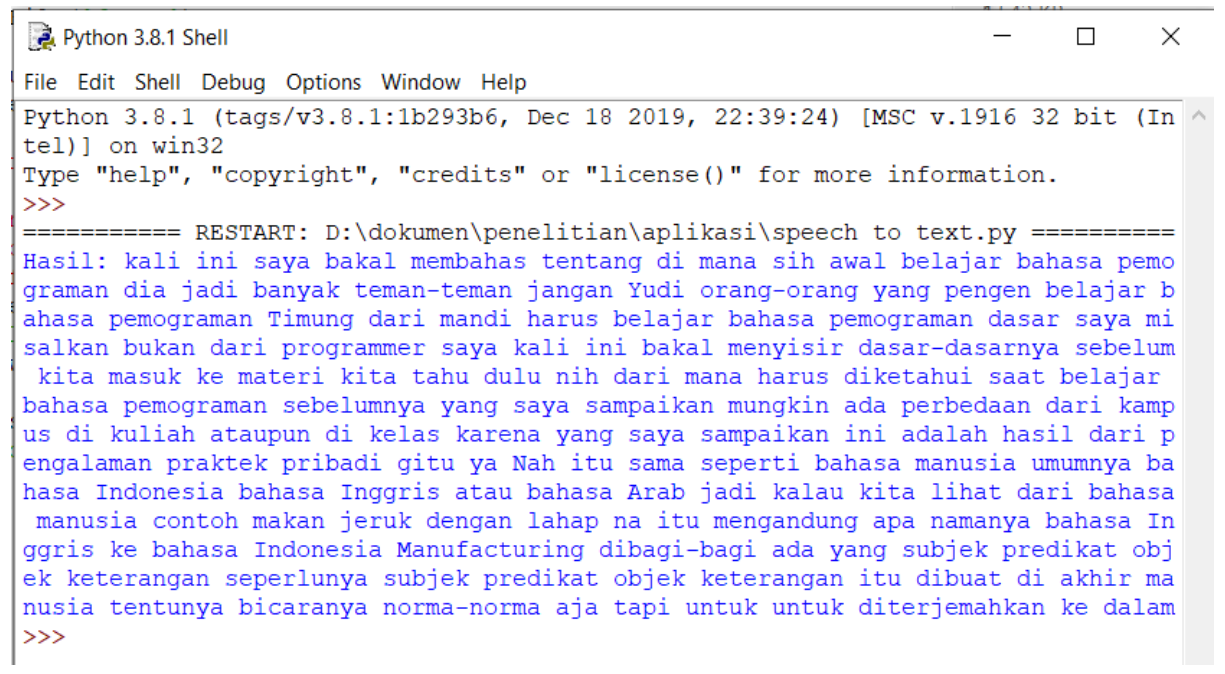

Gambar 8. File audio durasi 1 menit 32 detik.

Gambar 8 merupakan hasil yang didapat dengan durasi 1 menit 32 detik. Isi berita dari audio sample5.wav yaitu "Kali ini saya bakal membahas tentang di mana sih awal belajar bahasa pemograman, ini jadi banyak teman-teman yang newbie, orang-orang yang pengen belajar bahasa pemrograman bingung dari mana nih harus belajar bahasa pemrograman, dasar saya misalkan bukan dari programmer. Saya kali ini bakal menyisir, dasar-dasarnya sebelum kita masuk ke materi, kita tahu dulu nih dari mana harus diketahui saat belajar bahasa pemrograman. Sebelumnya yang saya sampaikan mungkin ada perbedaan dari kampus di kuliah ataupun di kelas, karena yang saya sampaikan ini adalah hasil dari pengalaman praktek pribadi gitu ya, nah itu sama seperti bahasa manusia umumnya, bahasa Indonesia, bahasa Inggris, atau bahasa Arab, jadi kalau kita lihat dari bahasa manusia, contoh makan jeruk dengan lahap, nah itu mengandung apa namanya grammar kalau bahasa Inggris kalau bahasa 
Indonesia mengandung strukturnya, dibagi-bagi ada yang subjek, predikat, objek, keterangan. Sebetulnya, subjek predikat objek keterangan itu dibuat di akhir, jadi manusia tentunya bicaranya norma-norma aja tapi untuk diterjemahkan ke dalam". Dari hasil pada Gambar 8, terlihat bahwa dari 156 kata dengan durasi 1 menit 32 detik, dapat menerjemah secara benar sebanyak 149 kata. Dari data tersebut, hasil dari aplikasi 95,6\% berhasil diterjemahkan ke teks.

6. Menggunakan file sample6.wav dengan durasi 2 menit Sample audio yang digunakan dengan merekam suara sendiri.

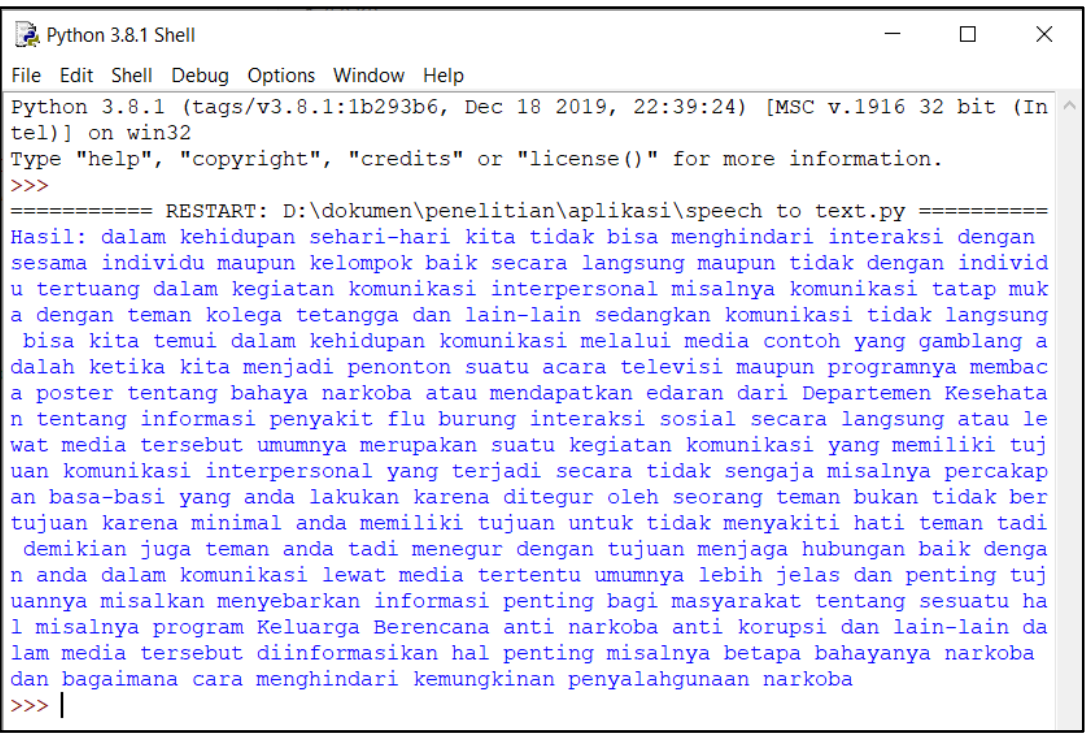

Gambar 9. File audio durasi 2 menit.

Gambar 9 merupakan hasil yang didapat dengan durasi 2 menit. Isi berita dari audio sample6.wav yaitu "Dalam kehidupan sehari-hari, kita tidak bisa menghindari interaksi dengan sesama individu maupun kelompok, baik secara langsung maupun tidak. Interaksi dengan individu tertuang dalam kegiatan komunikasi interpersonal, misalnya komunikasi tatap muka dengan teman, kolega, tetangga, dan lainlain. Sedangkan komunikasi tidak langsung bisa kita temui dalam kehidupan komunikasi melalui media. Contoh yang gamblang adalah ketika kita menjadi penonton suatu acara televisi apa pun programnya, membaca poster tentang bahaya narkoba atau mendapatkan edaran dari Departemen Kesehatan tentang informasi penyakit flu burung. Interaksi sosial secara langsung atau lewat media tersebut umumnya merupakan suatu kegiatan komunikasi yang memiliki tujuan tertentu. Komunikasi interpersonal yang terjadi secara tidak sengaja, misalnya percakapan basa-basi yang Anda lakukan karena ditegur oleh seorang teman, bukan tidak bertujuan karena minimal Anda memiliki tujuan untuk tidak menyakiti hati teman tadi. Demikian juga teman Anda tadi menegur dengan tujuan menjaga hubungan baik dengan Anda. Dalam komunikasi lewat media tertentu umumnya lebih jelas dan penting tujuannya, misalkan menyebarkan informasi penting bagi masyarakat tentang sesuatu hal, misalnya program Keluarga Berencana, anti narkoba, anti korupsi, dan lain-lain. Dalam media tersebut diinformasikan hal penting, misalnya betapa bahayanya narkoba dan bagaimana cara menghindari kemungkinan penyalahgunaan narkoba". Dari hasil pada Gambar 9, terlihat bahwa dari 186 kata dengan durasi 2 menit, dapat menerjemah secara benar sebanyak 185 kata. Dari data tersebut, hasil dari aplikasi 99,5\% berhasil diterjemahkan ke teks.

\section{Kesimpulan}

Kesimpulan yang dapat diambil dari penelitian ini adalah :

a) Aplikasi untuk speech to text dengan menggunakan bahasa pemrograman Python berhasil dibuat.

b) Modul speech recognition dan algoritma FastICA pada bahasa pemrograman Python, mampu mengonversi suara berupa rekaman suara orang dengan format .wav ke tulisan/teks, namun tanda baca tidak bisa dibuat oleh aplikasi ini. Dari hasil uji coba yang sudah dilakukan tingkat keberhasilan mencapai $94,75 \%$. 


\section{Daftar Pustaka}

[1] S. Ecip and dkk, Teknik Mencari dan Menulis Berita, 3rd ed. Tangerang Selatan: Universitas Terbuka, 2016.

[2] P. Khilari and Prof. Bhope, "Implementation Of Speech To Text Conversion," Int. J. Innov. Res. Sci. Eng. Technol., vol. 4, no. 7, 2015.

[3] A. Trivedi, N. Pant, P. Shah, S. Sonik, and S. Agrawal, "Speech to text and text to speech recognition systems-Areview," IOSR J. Comput. Eng., vol. 20, no. 2, 2018.

[4] A. Katyal, A. Kaur, and J. Gill, “Automatic Speech Recognition: A Review," Int. J. Eng. Adv. Technol., vol. 3, no. 3, 2014.

[5] P. Khilari and P. Bhope, “A Review On Speech To Text Conversion Methods,” Int. J. Adv. Res. Comput. Eng. Technol., vol. 4, no. 7, 2015.

[6] I. B. Setiawan, M. Bezaleel, and A. S. Prasida, "Aplikasi Noise Reduction untuk Perbaikan Kualitas Suara pada Data Audio Menggunakan Algoritma FastICA,” J. Teknol. Informasi-Aiti, vol. 8, p. 2, 2011.

[7] N. Saideep, D. G. Kurup, and S. Tripathi, "Detection of closely spaced sinusoids in noise using FastICA algorithm," Int. Conf. Adv. Comput. Commun. Informatics, ICACCI, vol. 2017-Janua, pp. 305-309, 2017, doi: 10.1109/ICACCI.2017.8125858. 